\title{
INVESTIGATION OF SAUSAGES WITH QUERCETIN AND NATIVE QUERCETIN-CONTAINING RAW MATERIALS OF EXTENDED SHELF LIFE
}

\author{
N. Hrehirchak, L. Peshuk, K. Zusko, T. Ivanova, O. Zabolotnya \\ National University of Food Technologies
}

\begin{tabular}{|c|c|}
\hline Key words: & ABSTRACT \\
\hline $\begin{array}{l}\text { Quercetin } \\
\text { Technology } \\
\text { Sausages } \\
\text { Microbiological safety } \\
\text { Onion husks }\end{array}$ & \multirow{3}{*}{$\begin{array}{l}\text { The article analyzes the preselected quercetin-containing } \\
\text { plant raw materials, which are safe and affordable for the } \\
\text { technology of production of meat products, including sau- } \\
\text { sages. The optimum concentration and method of prepara- } \\
\text { tion of the product under study was established. Peroxide } \\
\text { and acid numbers were determined, microbiological studies } \\
\text { of meat products with various additives during storage were } \\
\text { conducted. The compliance of the test samples with the } \\
\text { established standards has been proved. The dynamics of } \\
\text { changes in the level of total insemination of the submitted } \\
\text { samples of meat products during storage, as well as the } \\
\text { effect of various additives on their microbiological safety, } \\
\text { are revealed. }\end{array}$} \\
\hline $\begin{array}{l}\quad \text { Article history: } \\
\text { Received 11.05.2017 } \\
\text { Received in revised form } \\
02.06 .2017 \\
\text { Accepted } 22.06 .2017\end{array}$ & \\
\hline $\begin{array}{l}\text { Corresponding author: } \\
\text { N. Hrehirchak } \\
\text { E-mail: } \\
\text { npnuht@ukr.net }\end{array}$ & \\
\hline
\end{tabular}

DOI: $10.24263 / 2225-2924-2017-23-4-29$

\section{ДОСЛІДЖЕННЯ СОСИСОК 3 ВКЛЮЧЕННЯМ КВЕРЦЕТИНУ ТА НАТИВНОЇ КВЕРЦЕТИНВМІСНОї СИРОВИНИ ПОДОВЖЕНОГО ТЕРМІНУ ЗБЕРІГАННЯ}

\author{
Н.М. Грегірчак, Л.В. Пешук, К.В. Зусько, Т.М. Іванова, О.О. Заболотня \\ Національний університет харчових технологій
}

У статті проаналізовано попередньо відібрано квериетинвмісну рослинну сировину, яка є безпечною і доступною для технології м'ясних продуктів, в тому числі $i$ сосисок. Встановлено оптимальну концентрацію $i$ спосіб приготування досліджуваного продукту. Визначено пероксидне $і$ кислотне числа, проведено мікробіологічні дослідження м'ясних виробів з різними добавками в прочесі зберігання. Відмічено відповідність досліджуваних зразків встановленим нормативам. Виявлено динаміку зміни рівня загального обнасінення представлених зразків м'ясних виробів при зберіганні, вплив різних добавок на їх мікробіологічну безпеку.

Ключові слова: кверцетин, технологія, сосиски, мікробіологічна безпека, лушииння циибулі. 
Постановка проблеми. На українському ринку продовольчих товарів м'ясо і м'ясні продукти мають особливий статус, тому що складають основу раціону населення. Значним попитом користуються і сосиски варені. Проте окиснювальні процеси жирів у будь-яких м'ясних продуктах негативно впливають на їх органолептичні показники, сприяють зниженню харчової та біологічної цінності, що пов'язано з утворенням і накопиченням продуктів окислення, які характеризуються високою реакційною здатністю і хімічною активністю та $\epsilon$ токсичними й антиаліментарними речовинами. Причинами окислення є підвищена температура, вільний доступ кисню і наявність іонів металів змінної валентності. Тому для запобігання окислювальному псуванню необхідним $є$ виключення впливу даних факторів на продукт. Для багатьох харчових продуктів, в тому числі і м'ясних, істотно уповільнити окислення можна за допомогою антиокислювачів [1].

Антиоксиданти (антиокислювачі) відносяться до розряду інгібіторів (речовини, що сповільнюють перебіг певної хімічної реакції), можуть бути як природними, так і синтетичними [2]. Зазвичай у м'ясній промисловості використовуються такі синтетичні антиоксиданти: бутилгідроокситолуол (ВНТ, іонол Е321), бутилгідрооксианізол (БОА, Е320) ізоаскорбінова кислота (Е315), ізоаскорбат натрію (Е316), нормована доза використання яких становить $0,02 \%$ [3].

Проте використання синтетичних антиоксидантів у харчовій промисловості обмежено через токсичність, високу вартість, необхідність суворого контролю. Тому нині велика увага приділяється пошуку натуральних добавок, що містять природні антиоксиданти, безпосередньо флаваноїди (рутин, гесперидин, гіперозид, кверцетин, кемпферол і апігенін). Найбільш поширеним антиоксидантом біофлаваноїдом є кверцетин (Quercetin), який класифікується як флавонол - один із 6 класів флавоноїдів. За фізичними властивостями флавоном являє собою жовті кристали, розчинні в етанолі і нерозчинні у воді, молярна маса яких складає 302,236 г/моль [4]. Антиоксидантна активність кверцетину обумовлена його здатністю пригнічувати процеси перекисного окислення ліпідів, знижувати вміст не тільки вільних радикалів, а й токсичних продуктів перекисного окислення. Отже, дана речовина має стимулюючий вплив на антиоксидантну систему організму. Великий вміст кверцетину виявлено в лушпинні цибулі (40000 мг/кг) [5]. Крім того кверцетин $є$ складовою хімічного складу квіток мати-й-мачухи [6].

Порівнюючи різні джерела кверцетинвмісної сировини, відмічено, що лушпиння і верхні лусочки цибулі є найбагатшими джерелами кверцетину. Загальний вміст кверцетину і антиоксидантний потенціал в червоній, жовтій $\mathrm{i}$ білій сортах цибулі були дослідженні і описані в працях Xiao Nan Yang, Enning Xu, Mi Jin Park,In Jong Ha, Jin Seong Moon, Young-Hwa Kang. Особливий інтерес представляє цибуля жовта ріпчаста (лат. Allium cepa), оскільки це найбільш поширена культура цибулевих на території України. У світі об'єми виробництва цибулі ріпчастої за рік складають близько 55 млн тонн. ВУкраїні за минулий рік було отримано 11413,0 тис. ц [7]; частка відходів $10-30 \%$ залежно від виду цибулі і умов вирощування [8].

Глікозиди кверцетину не деградують при приготуванні водних витяжок лушпиння і лусочок цибулі. Експериментальними дослідженнями Lines T.C., 
Ono M.P. на щурах доведено, що екстракт лушпиння цибулі (ЕЛЦ) досить ефективно посилює антиоксидантний захист, покращує ендотеліальну функцію як в експериментальних щурів, так і в людей, що сприяє зниженню артеріального тиску. Таким чином, цибулиння може бути перероблено в екстракт чи порошок і використовуватись для профілактики захворювань, в патогенезі яких лежить окисний стрес. Крім того, в лушпинні цибулі міститься велика кількість активних речовин [9-10]. Тому використання лушпиння цибулі в рецептурі м'ясних виробів $є$ актуальним і потребує подальших досліджень.

Мета досліджень: проаналізувати перспективи використання нативної кверцетинвмісної сировини (лушпиння цибулі та мати-й-мачухи) у технології сосисок для подовження терміну їх зберігання.

Матеріали і методи. Об'єктами дослідження були сосиски з м'яса птиці, яловичини, м'яса птиці механічного обвалювання, з додаванням кверцетину хімічно чистого (виробник нім. компанія Merck), упарених водних екстрактів лушпиння цибулі (ЕЛЦ) та лікарської трави мати-й-мачухи (ЕЛТМ).

Як контрольний зразок використовували сосиски першого сорту за рецептурою й технологічним процесом виробництва згідно ТУ У 10.138348641-001:2013 «Вироби ковбасні варені, сосиски, сардельки, хліби м'ясні та м'ясомісткі» без додавання кверцетину та водних екстрактів кверцетинвмісної нативної сировини. Термін зберігання згідно з ДСТУ 4529:2006 «Ковбаси варені $з$ м'яса птиці та м'яса кролів. Загальні технічні умови» для таких сосисок становить не більше 8 діб у вологонепроникній поліамідній оболонці.

Попередньо досліджено приготовлений ЕЛЦ та ЕЛТМ на концентрацію кверцетину [11]. ЕЛЦ та ЕЛТМ для сосисок готували таким чином: воду доводили до кипіння, засипали в киплячу воду відважену кількість лушпиння 3 цибулі чи лікарської трави мати-й-мачухи у кількості 4\%, кип'ятили 10 хв, охолоджували, проціджували, упарювали в 10 разів і додавали з розрахунку 0,225 мг кверцетину в 1 мл, щоб отримати 0,02\%-ву концентрацію кверцетину в готових виробах.

При виконанні роботи використовували стандартні фізико-хімічні методи досліджень, а також визначали кислотне й пероксидне числа $[12 ; 13]$.

Мікробіологічні дослідження розроблених сосисок здійснювали згідно 3 методиками, затвердженими Міністерством охорони здоров'я і державними стандартами (ДСТУ ISO 18593:2006; 6887-2:2005; 4833:2006; 4832:2006; 7937-2006; 7954:2006, ГОСТ 7702.2.4-93). Контролювали кількість мезофільних аеробних і факультативно-анаеробних мікроорганізмів (КМАФАнМ), спороутворювальних бактерій (СУБ), наявність бактерій групи кишкової палички (БГКП), мезофільних сульфітредукуючих клостридій та Staphylococcus aureus, кількість дріжджів і пліснявих грибів.

Дослідження динаміки зміни показників мікробіологічної безпеки і стабільності, а також окиснювальних процесів виготовлених сосисок у процесі зберігання проводили одразу після приготування, на 3, 7, 10, 12 та 15 добу. Досліджувані зразки зберігали при температурі $0 \ldots 6^{\circ} \mathrm{C}$. 
Результати і обговорення. На процеси окислення у виготовлених м'ясних продуктах впливає вміст вологи та вміст жиру. Тому було досліджено фізикохімічні показники розроблених сосисок (вміст вологи, жиру, золи, білку), які характеризують технологічні властивості виробів до- та після термічної обробки і доводять позитивний вплив запропонованих технологічних заходів на формування споживчих властивостей готових виробів (табл. 1).

Таблиия 1. Фізико-хімічні показники сосисок до- та після термічної обробки, \%

\begin{tabular}{|c|c|c|c|c|c|c|c|c|}
\hline \multirow{2}{*}{ Назва зразка } & \multicolumn{2}{|c|}{ Вміст вологи } & \multicolumn{2}{|c|}{ Вміст жиру } & \multicolumn{2}{|c|}{ Вміст білку } & \multicolumn{2}{|c|}{$\begin{array}{c}\text { Вміст } \\
\text { мінеральних } \\
\text { речовин } \\
\end{array}$} \\
\hline & $\begin{array}{c}\text { до } \\
\text { терм. } \\
\text { обр } \\
\end{array}$ & $\begin{array}{c}\text { після } \\
\text { терм. } \\
\text { обр } \\
\end{array}$ & $\begin{array}{c}\text { до } \\
\text { терм. } \\
\text { обр } \\
\end{array}$ & $\begin{array}{l}\text { після } \\
\text { терм. } \\
\text { обр } \\
\end{array}$ & $\begin{array}{c}\text { до } \\
\text { терм. } \\
\text { обр }\end{array}$ & $\begin{array}{c}\text { після } \\
\text { терм. } \\
\text { обр } \\
\end{array}$ & $\begin{array}{c}\text { до } \\
\text { терм. } \\
\text { обр } \\
\end{array}$ & $\begin{array}{c}\text { після } \\
\text { терм. } \\
\text { обр } \\
\end{array}$ \\
\hline $\begin{array}{c}\text { ДСТУ 4529:2006 } \\
\text { «Ковбаси варені з м’яса } \\
\text { птиці та м’яса кролів. } \\
\text { Загальні технічні } \\
\text { умови» }\end{array}$ & \multicolumn{2}{|c|}{$\begin{array}{c}\text { не більше ніж } \\
75,0\end{array}$} & \multicolumn{2}{|c|}{$\begin{array}{c}\text { не більше ніж } \\
30,0\end{array}$} & \multicolumn{2}{|c|}{$\begin{array}{c}\text { не менше ніж } \\
10,0-12,0\end{array}$} & \multicolumn{2}{|c|}{ не нормується } \\
\hline Контроль & 72,5 & 72,3 & 10,59 & 10,62 & 15,33 & 15,35 & 1,58 & 1,73 \\
\hline $\begin{array}{c}\text { Сосиски з кверцетином } \\
\text { німецької компанії } \\
\text { Merck } \\
\end{array}$ & 72,0 & 72,1 & 10,60 & 10,59 & 15,43 & 15,41 & 1,96 & 1,90 \\
\hline $\begin{array}{c}\text { Сосиски з екстрактом } \\
\text { лушпиння цибулі }\end{array}$ & 72,1 & 72,0 & 10,54 & 10,54 & 15,40 & 15,39 & 1,96 & 2,07 \\
\hline $\begin{array}{c}\text { Сосиски з екстрактом } \\
\text { мати-й-мачухи }\end{array}$ & 72,2 & 72,1 & 10,50 & 10,53 & 15,37 & 15,33 & 1,93 & 2,04 \\
\hline
\end{tabular}

Дані, отримані в результаті дослідження фізико-хімічних показників експериментальних зразків готових сосисок, відповідають вимогам ДСТУ 4529:2006 «Ковбаси варені 3 м'яса птиці та м'яса кролів. Загальні технічні умови». Так, вміст вологи - не більше ніж 75,0\%, вмісту жиру — не більше ніж $30,0 \%$ та вміст білка - не менше ніж 10,0-12,0\%. Як видно 3 табл. 1 , додані кверцетин і кверцетинвмісна нативна сировина суттєво не впливають на вміст вологи, жиру та білка.

Відомо, що в процесі зберігання сосисок проходять окислювальні процеси і поступово зростає кислотне (КЧ) та пероксидне числа (ПЧ) [14]. Тому важливо дослідити динаміку окислювальних процесів даних виробів у процесі зберігання. При встановленні граничних значень ПЧ і КЧ для сосисок нової рецептури враховували вміст в них жиру: перекисне число - не більше 10 ммоль 1/2О/кг, кислотне число - не більше 1,1 мг КОН.

Беручи до уваги, що вміст жиру в контрольному зразку становив $14,65 \%$, то нормоване значення ПЧ для нього не повинно перевищувати 1,5 ммоль $\mathrm{O}_{2} / \kappa г$, а КЧ, відповідно, - не більше 0,96 г КОН / кг. Для рецептур з додаванням кверцетину або екстракту з лушпиння цибулі, або екстракту з мати-й-мачухи, де вміст жиру становить $10,60 \%, 10,54 \%, 10,50 \%$ відповідно, нормоване значення ПЧ не повинно перевищувати 0,9 ммоль $\mathrm{O}_{2} /$ кг продукту, а КЧ - не більше 0,9 г КОН/кг (рис. $1-2$ ). 


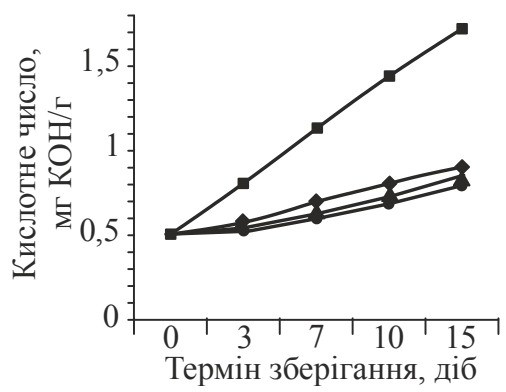

- Контроль

- Сосиски з екстрактом лушпиння цибулі

- Сосиски з кварцетином німецької компанії Merk

^ Сосиски з екстрактом мати-й-мачухи

Рис. 1. Динаміка зміни кислотного числа в сосисках в процесі зберігання

3 рис. 1 видно, що контрольний зразок перевищує розраховані норми КЧ і становить вже на 7-му добу 1,2 мг КОН. Розроблені рецептури мають кращу стійкість до окиснення, оскільки не спостерігалось перевищення нормативу навіть на 12-ту добу.

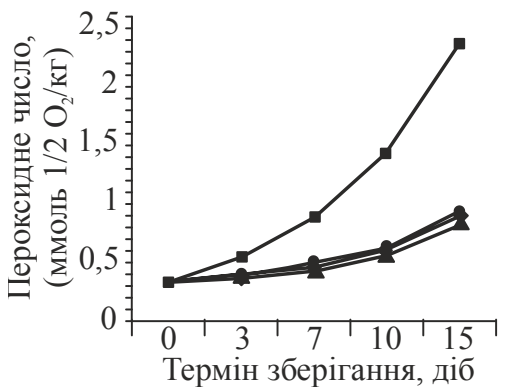

- Контроль

- Сосиски з кварцетином німецької компанії Merk

- Сосиски з екстрактом лушпиння цибулі

^ Сосиски з екстрактом мати-й-мачухи

Рис. 2. Динаміка зміни пероксидного числа в сосисках в процесі зберігання

3 рис. 2 видно, що розроблені рецептури на 12-й день зберігання мають допустимі значення ПЧ в порівнянні з контролем, який уже на 7-му добу перевищив норматив.

Відомо також, що добавки (кверцетин, екстракти цибулинного лушпиння, мати-й-мачухи тощо) багаті вітамінами А, В, C, Е, мікро-і макроелементами. До складу деяких 3 них входять також фітонциди, які мають антимікробні властивості, особливо щодо кишкових патогенних мікроорганізмів, золотистого стафілокока і $\alpha$-гемолітичних стрептококів. Додавання цих добавок у рецептуру м'ясних виробів, в тому числі сосисок, сприяє їх тривалішому зберіганню [15;16].

Оскільки кверцетин і нативна кверцетинвмісна сировина мають оптимальний склад активних речовин, то, відповідно, вони служать хорошим середовищем для розвитку мікроорганізмів і можуть сприяти подальшому псуванню м'ясних виробів [17]. Тому дослідження впливу даних добавок на мікробіологічну безпеку сосисок нової рецептури є дуже важливим для безпечного споживання продукту.

Так, мікробіологічний аналіз сосисок показав, що протягом 8 днів зберігання при $t=0 \ldots 6^{\circ} \mathrm{C}$, незалежно від добавок та сировини, що використовували при їх приготуванні, вони відповідають встановленим санітарно-мікробіоло- 
гічним нормативам та є безпечними для споживання. У сосисках з кверцетинвмісною сировиною перевищення нормативної КМАФАнМ $\left(1 \cdot 10^{3} \mathrm{KУО/г)} \mathrm{й}\right.$ кількості пліснявих грибів не спостерігалося порівнянно з контролем, де вже на 7-й день зберігання визначено перевищення нормативу (рис. 3). Бактерій групи кишкової палички, сульфітредукувальних клостридій і золотистого стафілокока в досліджених продуктах не виявлено, що свідчить про дотримання санітарно-гігієнічних норм при їх приготуванні.

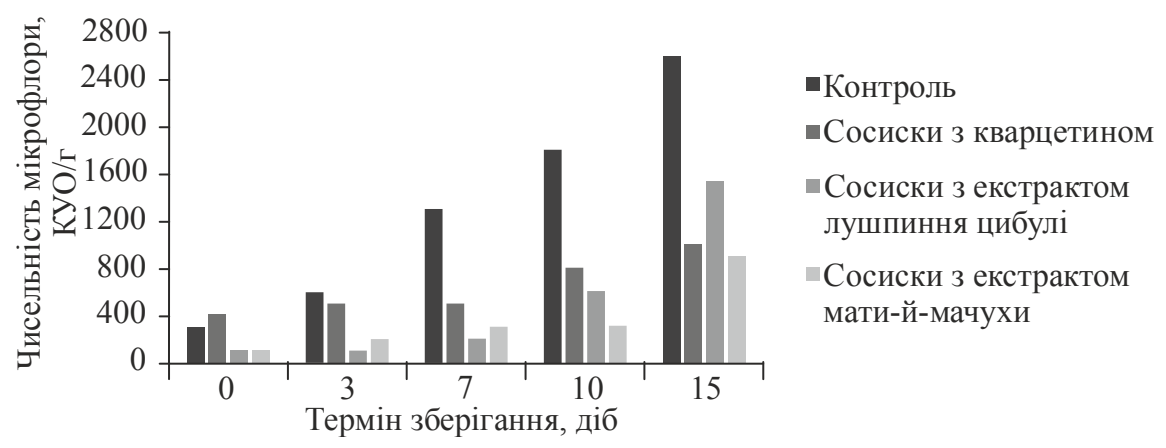

Рис. 3. Зміна показника КМАФАнМ в процесі зберігання сосисок

Відомо, що спороутворювальні бактерії здатні розмножуватись у м'ясних виробах і спричиняти харчові отруєння [17]. Тому нами було досліджено зміну спороутворювальних бактерій у процесі зберігання сосисок нової рецептури.

Вміст спороутворювальних бактерій у всіх зразках нестабільний, на десяту добу найбільша їх кількість в контролі та зразку з вмістом екстракту мати-й мачухи. При подальшому зберіганні в зразках з екстрактами мати-й-мачухи та лушпиння цибулі зменшувалась кількість спороутворювальних бактерій, а в зразках з кверцетином та контролі, навпаки, дещо зростала (рис. 4).

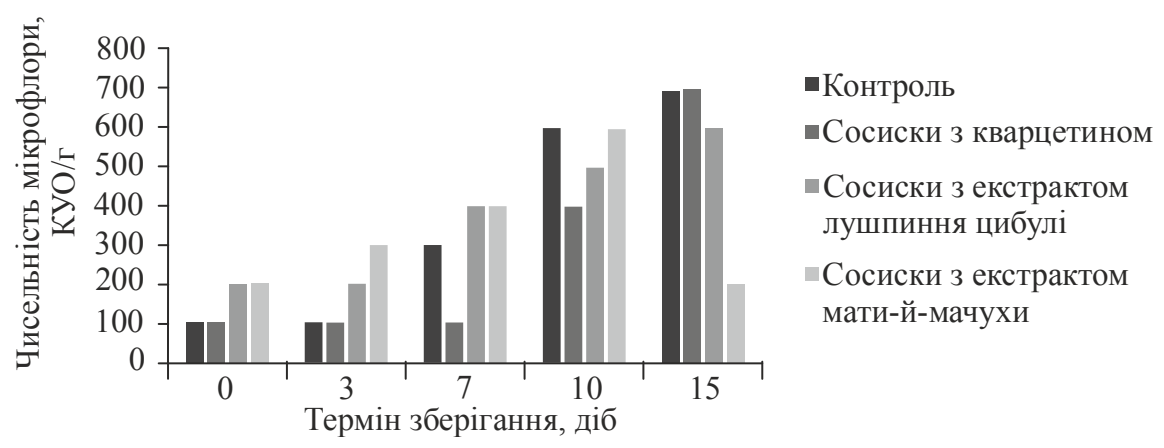

Рис. 4. Зміна кількості спороутворювальних бактерій у процесі зберігання сосисок

Аналіз морфотипів колоній, виділених із сосисок, показав, що всі зразки мають декілька спільних видів колоній мікроорганізмів. Під час зберігання їх співвідношення змінюються, що можна пояснити здатністю певних мікроорганізмів краще засвоювати поживні речовини досліджуваного продукту. Так, спільними для всіх зразків сосисок були колонії бактерій білого кольору з нерівними краями і випуклим профілем та білі круглі колонії. 
Також було визначено, що сосиски 3 добавками екстрактів мати-й-мачухи й кверцетину є безпечними для споживачів навіть на 15-й день зберігання, так як не спостерігалося перевищення показника КМАФАнМ відповідно до норми (рис. 3). Це можна пояснити антимікробними властивостями добавок, використовуваних при приготуванні м’ясних виробів (табл. 2).

Таблиця 2. Антагоністична активність екстрактів мати-й-мачухи і цибулинного лушпиння

\begin{tabular}{|c|c|c|}
\hline \multirow{2}{*}{ Тест-культури } & \multicolumn{2}{|c|}{ Зона затримки, мм } \\
\cline { 2 - 3 } & екстракт мати-й-мачухи & екстракт лушпиння цибулі \\
\hline B. subtilis БТ-2 & 3 & 6 \\
\hline E. coli IEM-1 & 0,00 & 0,00 \\
\hline Pseudomonas sp.MI-2 & 6 & 10 \\
\hline C. albicans Д-6 & 0,00 & 0,00 \\
\hline
\end{tabular}

Примітка: * стат. рівень значимості $p \leq 0,05$

Дані таблиці 2 засвідчують, що екстракти мати-й мачухи й лушпиння цибулі мають дещо бактеріостатичну дію, оскільки спостерігається затримка росту деяких мікроорганізмів (B. subtilis БТ-2, Pseudomonas sp. MI-2).

Проведені фізико-хімічні, мікробіологічні дослідження доведели ефективність використання в рецептурі сосисок кверцетину та нативної кверцетинвмісної сировини. У результаті отримано продукт з подовженим терміном зберігання, тому в подальшому треба провести дослідження впливу такого продукту in vivo.

\section{Висновок}

Отже, використання в рецептурі сосисок кверцетину та нативної кверцетинвмісної сировини дає змогу отримати збалансований продукт, що має високі технологічні й споживчі властивості та $€$ безпечним навіть після закінчення нормованого терміну зберігання.

\section{Література}

1. Домнина Н.С. Антиоксиданты и методы изучения их активности / Н.С. Домнина, Е.А. Комарова, Д.В. Арефьев, О.А. Ролле, М.М. Цыбра // Ветеринария в птицеводстве. 2004. 一№ 4. - C. 8 - 20 .

2. Савельева Ю.С. Антиоксиданты в мясной промышленности / Ю.С. Савельева, Е.А. Ветошкина, А.С. Комарова //Материалы V Всероссийской научно-практической Интернет-конференции «Мясная и молочная промышленность России: состояние, проблемы, перспективы» [Электронный ресурс]. - Режим доступа : http://tkmmp.ru/nmr.

3. Кушнир Ю. Пищевые добавки для производства мясной продукции. Антиокислители // Мясной бизнес. - 2004, —№ 1(19). - С. 26-31.

4. Kelly G.S. Quercetin Alternative Medicine review. - 2011. - Vol. 16, No 2. - P. 172-194.

5. Ковалевська I.B. Визначення фізико-хімічних характеристик кверцетину // Фармакогнозія та хімія природних сполук. - Выпуск № 1(14) - 2014. - С. 245.

6. Бельтюкова С.В. Люминесцентное определение флавонолов как индикаторных компонентов растительного лекарственного сырья научно-практическая конференция биологически активные вещества: фундаментальные и прикладные вопросы получения и применения / С.В. Бельтюкова, А.А. Бычкова. — Новый Свет, Крым, Украина. — 2009. — С. 17. 
7. Офіційний сайт Державної служби статистики України [Електронний ресурс]. Режим доступу : http://www.ukrstat.gov.ua.

8. Завадська O.В. Підбір для сушіння сортів цибулі ріпчастої, вирощеної в умовах лісостепу України / О.В. Завадська, О.В. Дяденко // Науковий вісник Національного університету біоресурсів і природокористування України. Сер. : Агрономія. — 2012. Вип. 176. - С. 247-252.

9. Lines T.C., Ono M.P. An extract of red onion peel, strong inhibit sphosphodiesterase 5A (PDE 5A) // Phytomedicine. — 2006. — №13(4) - P. 236-239.

10. KimY.J., Seo S. G., Choi K., Kim J.E., Kang H., Chung M.Y., Lee K.W., Lee H.J. Recovery effect of onion peel extract against $\mathrm{H} 2 \mathrm{O} 2$-induced inhibition of gap-junctional intercellular communication is mediated through quercetin // Journal of Food Science. — 2014. №79(5). - P. 1011-1017.

11. Пешук Л.В. Перспективи використання вторинної кверцетинвмісної сировини (лушпиння цибулі і часнику) і лікарських трав у технології спеціальних м'ясних продуктів / Л.В. Пешук, Ю.В. Гавалко, Т.М. Іванова // Наукові праці Національного університету харчових технологій. - Київ. - 2016. - Т. 22, № 5. - С. 238-244.

12. ДСТУ ISO 3960-2001 «Жири і олії тваринні і рослинні. Визначання пероксидного числа (ISO 3960:1998, IDT). — Офіц. вид. — Чинний від 01.01.2003. — Київ : Державний комітет України з питань технічного регулювання та споживчої політики, 2002. — IV, 6 с.

13. ДСТУ 4350: 2004. Олії. Методи визначання кислотного числа (ISO 660: 1996, NEQ) [Електронній ресурс]. - Режим доступу : http://www.twirpx.com/file/1434399/.

14. Никитченко Д.В. Оценка качественных показателей мяса птицы механической обвалки [Текст / Д.В. Никитченко, М.А. Яцюта, В.Е. Никитченко, В.Н. Перевозчикова // Мясная индустрия. - 2012. - № 4. - С. $62-63$.

15. Кверцетин - мощное оружие против комплекса болезней цивилизаци // Medical Nature. - 2013. - № 1. - С. 6 -9.

16. Стадницька Н.С. Рослини з протимікробними властивостями / Н.С. Стадницька, О.3. Комаровська-Порохнянець, Х.Я. Кіщак // Вісник Національного університету «Львівська політехніка». — 2011. — № 700. — С. 111-116.

17. Баль-Прилипко Л.В. Влияние различных факторов на срок и качество хранения мясных продуктов // Мясное дело. — 2006. — № 8. - С. 53-55. 